\title{
People in Political Science
}

\section{Activities}

Ira H. Carmen, University of Illinois at Urbana-Champaign, has been appointed to the Recombinant DNA Advisory Committee (RAC) of the National Institutes of Health. Carmen is the second political scientist to sit on the committee. He will serve a four-year term while continuing his on-campus professorial responsibilities.

Jeanne-Marie Col, associate professor of public administration at Sangamon State University, is serving as chair of the program committee of the national conference of the American Society for Public Administration, to be held in Los Angeles in April 1990, and was recently elected to the Board of Management of the International Association of Schools and Institutes of Administration. During AY 89-90, Col is on sabbatical, working with the United Nations Development Administration Division.

\section{John H. Herz, CUNY Graduate}

Center, under a grant from the German Marshall Fund, lectured in fall 1989 on American foreign policy under the Bush Administration at the
University of Frankfurt and the Hessen Foundation for Conflict and Peace Research.

Hong N. Kim, professor, West Virginia University, is spending the 1989-90 academic year and summer 1990 in Korea on a Fulbright-Hays Research-Teaching Fellowship.

Richard Rose, University of Strathclyde, gave the 1990 Ransone Lectures in the University of Alabama's distinguished lecture series in March 1990. His subject was "Lesson Drawing Across Time and Space."

Rein Taagepera, University of California, Irvine, gave a course on electoral systems at the new Estonian Humanities Institute, the first private university within the present Soviet borders. He was elected to the General Committee of Citizens of Republic of Estonia that organized non-Soviet elections in February 1990.

\section{Administrative Appointments}

R. Douglas Arnold, chair, depart-

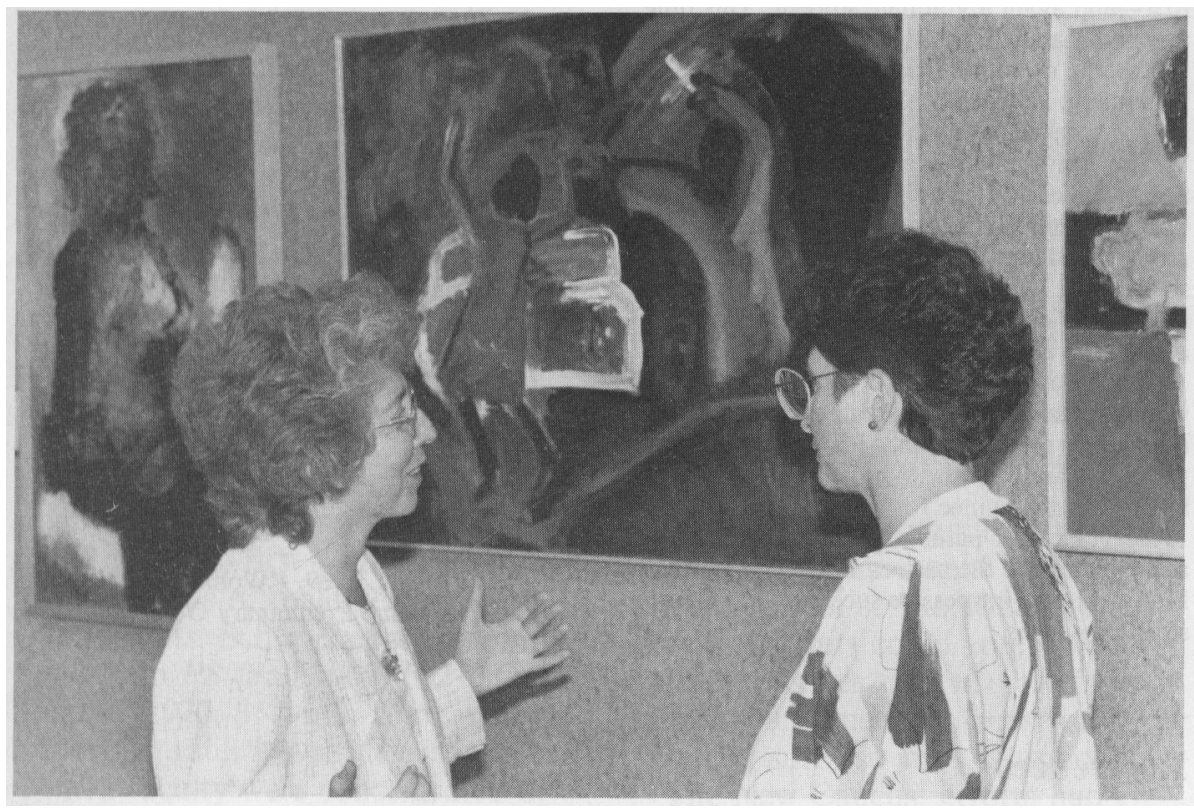

Virginia Cohn Parkum (l), Association of Voluntary Action Scholars, presents her painting "Emergency Decree: Liberation from the Golden Calf" to Ruth Leventhal, Provost, of the Pennsylvania State University at Harrisonburg.

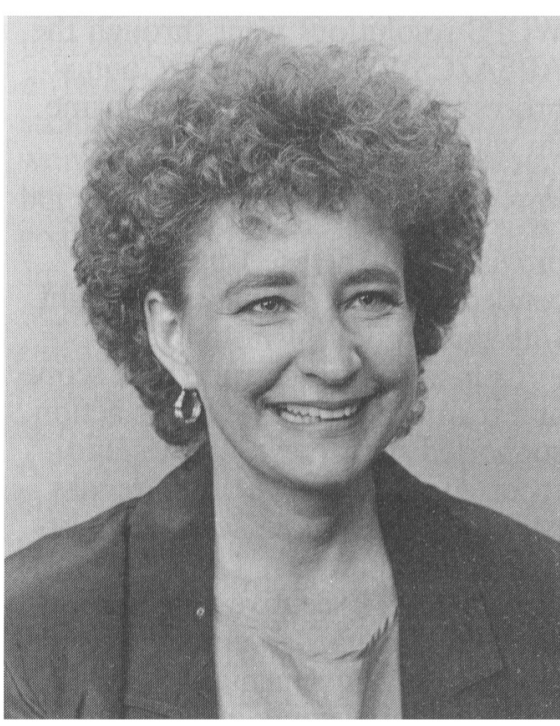

Jeanne-Marie Col

ment of politics, Princeton University, effective for 1990-91 academic year.

Roger E. Kanet, professor of political science at the University of Illinois, was recently appointed associate vice chancellor for academic affairs and director of international programs and studies at the university.

John Kincaid, executive director, Advisory Commission on Intergovernmental Relations; formerly director of research at the commission.

Michael Margolis, head, department of political science, University of Cincinnati.

Lois Moreland, chair of the political science department at Spelman College, has been appointed director of a new International Affairs Center, which will serve Spelman, Morehouse, and Morris Brown Colleges and Clark Atlanta University.

Robert B. Zajonc, director, Institute for Social Research, University of Michigan, Ann Arbor.

\section{New Appointments}

Lawrence J. Biskowski, assistant professor of political science, Univer- 


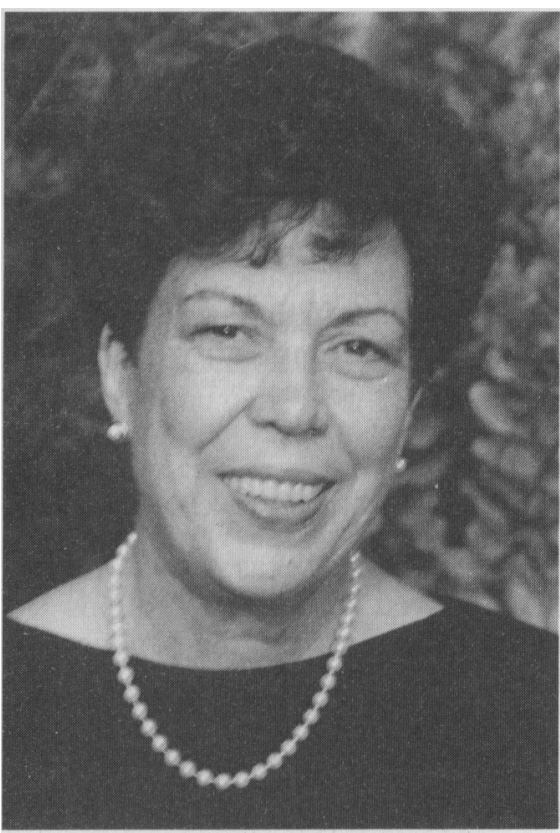

Fran Burke

sity of Georgia.

Maria Chang, associate professor of political science, University of Nevada, Reno; formerly of Puget Sound.

William D. Duncombe, assistant professor of political science, University of Georgia.

Eric Herzik, associate professor of political science, University of Nevada, Reno; formerly Arizona State University. Herzik has also been appointed as director of the MPA program and coordinator of graduate studies for the department of political science at Nevada.

Karen J. Maschke, assistant professor of political science, University of Georgia.

Daniel J. Palazzolo, assistant professor of political science, University of Richmond.

Carol M. Swain, assistant professor of public affairs and politics, Woodrow Wilson School, Princeton University.

\section{Promotions}

Robert V. Bartlett, associate professor with tenure, department of political science, Purdue University.

Adam Clymer, Senior Editor for Weekend, New York Times.
Robert D. Duval, associate professor, West Virginia University.

Arnold J. Fleischmann, associate professor with tenure, University of Georgia, effective September 1990.

Stephen M. Meyer, professor, Massachusetts Institute of Technology.

Don T. Nakanishi, associate professor with tenure, University of California, Los Angeles.

Hal G. Rainey, professor of political science, University of Georgia, has been awarded tenure effective September 1990.

Richard Valelly, associate professor, Massachusetts Institute of

Technology.

\section{Retirement}

Herbert G. Wilcox, professor, West Virginia University, August 1989.

\section{Visiting and Temporary Assignments}

Eleanor Blakely, visiting assistant professor, West Virginia University; formerly University of North Carolina at Chapel Hill.

Fran Burke will be Alice Tweed Tuohy visiting professor of government and ethics at Claremont McKenna College for academic year 1989-90.

Khai Ho, visiting professor, West Virginia University; formerly Ohio State University.

Richard I. Hofferbert, State University of New York-Binghamton, will be visiting research professor at the Science Center-Berlin from January through August 1990 and visiting professor of political science at the University of Essex (England) during the fall 1990 semester.

Steven Kramer, visiting associate professor, department of government, Georgetown University, academic year 1989-90.

Michael Parenti was University of Canterbury Professor at the University of Canterbury, Christchurch, New Zealand, spring 1989; and Distinguished Resident Professor at

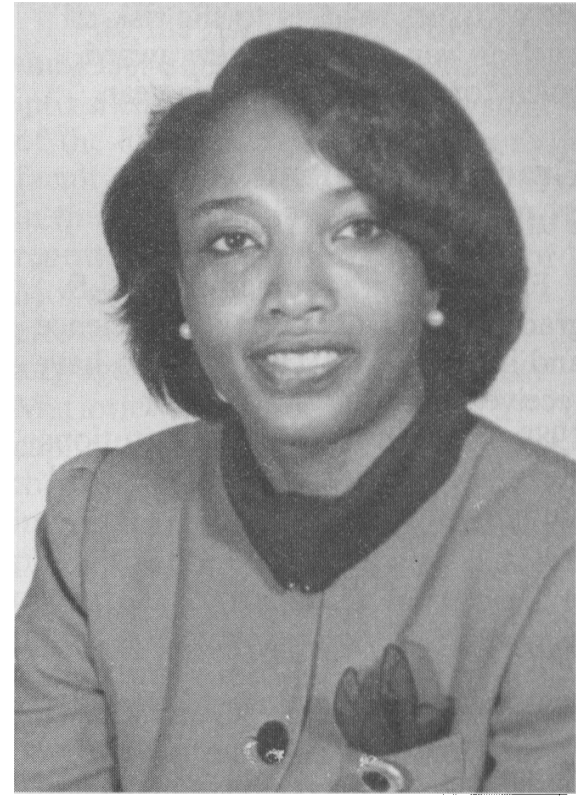

Carol Swain

California State University, Northridge, spring 1990.

\section{Award Recipients}

\section{National Academy of Sciences}

Robert Axelrod, distinguished university professor of political science and public policy at the University of Michigan has received the National Academy of Sciences Award for Behavioral Research Relevant to the Prevention of Nuclear War. With a prize of $\$ 5000$, the award recognizes basic research in the cognitive and behavioral sciences that uses rigorous formal and empirical methods to advance understand-

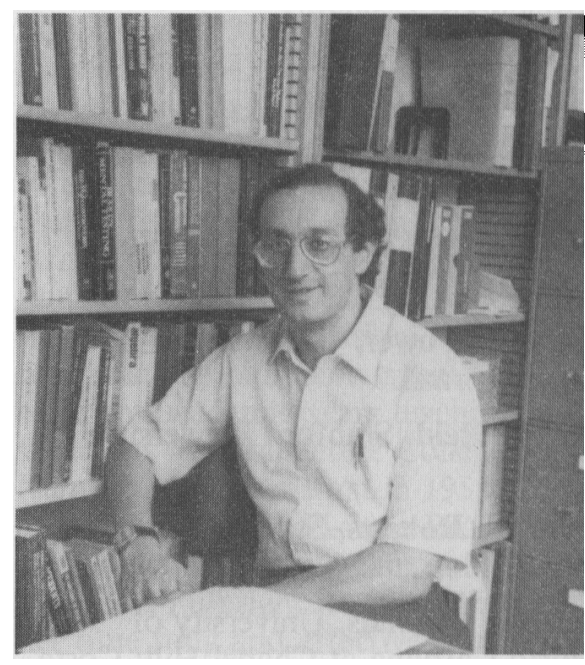

Robert Axelrod 